\title{
The judge, maritime delimitation and the grey areas
}

\author{
Tafsir Malick Ndiaye
}

Published online: 31 May 2016

(C) The Author(s) 2016. This article is published with open access at Springerlink.com

\begin{abstract}
The delimitation of maritime areas between neighbours is of vital importance in that it provides for stable and long-lasting relations. With the maritime boundary delimitation, international law has been enriched with a new chapter that has developed steadily in proportion with the related challenges and expectations. After nearly a century of practice, international courts and tribunals achieve a very useful result in boundary delimitation: a single maritime boundary employing the now well-established three-stage equidistance-relevant-circumstances method. The paper examines the Wade-mecuum of the move and the emergence of jurisprudence addressing delimitation of a State's maritime entitlements located beyond 200 nautical miles from the baselines, i.e., the so-called Outer Continental Shelf and the legal regime thereof.
\end{abstract}

Keywords The UNCLOS · The ITLOS · Maritime delimitation

\section{Introduction}

With maritime delimitation, international law has been enriched with a new chapter that has developed rapidly in proportion with the related challenges and expectations. The delimitation of maritime areas between neighbours is of vital importance in that it provides for stable and long-lasting relations.

The author is a Judge of the International Tribunal for the Law of the Sea, Hamburg, Germany. Opinions expressed in this article are personal.

Tafsir Malick Ndiaye $(\bowtie)$

International Tribunal for the Law of the Sea, Hamburg, Germany

e-mail: ndiaye@itlos.org 
Many maritime boundaries in the world are, however, not delimited. The total number of potential maritime boundaries is $420,{ }^{1}$ yet there are only about 200 boundary agreements to date. This implies that disputes relating to maritime delimitation have many days ahead of them. To settle such disputes, States shall have to negotiate among themselves or use available dispute resolution mechanisms.

Customary law, developed progressively through conferences on codification and bilateral boundary agreements, appears a priori as an important source for maritime boundary delimitation law.

Proceedings of the UN International Law Commission led to the 1958 Geneva Conventions on the delimitation of the territorial sea and the continental shelf. The third United Nations Conference on the Law of the Sea gave rise to the United Nations Convention on the Law of the Sea (UNCLOS) of 10 December 1982. The latter provides for the delimitation of the territorial sea, the continental shelf and the economic exclusive zone. However, ${ }^{2}$ a review of maritime delimitation disputes reveals that these provisions hardly occupy the central place they are expected to. Moreover, bilateral boundary agreements have not produced adequate practice of the law to be able to impose itself as customary law.

The fundamental role in the formulation of legal rules and principles that should govern the law on maritime delimitation therefore appears to be the responsibility of the International Court of Justice (ICJ) and arbitrary tribunals. The tribunals apply the delimitation rules as indicated by the Court while occasionally introducing some innovations, which are later adopted by the ICJ in a spirit of mutual benefit. It is worth noting at this point that the International Tribunal for the Law of the Sea (ITLOS) was first seized of a maritime delimitation case with the presentation of the case on the dispute regarding the maritime boundary between Bangladesh and Myanmar in the Bay of Bengal on 14 December 2009. ${ }^{3}$

\footnotetext{
1 The US Dept of State, Bureau of Oceans and International Environment and Scientific Affairs, Limits in the Seas, No: 108, 1st Rev (Maritime Boundaries of the World, 1990).

2 It may be recalled that in the North Sea Continental Shelf (Germany v Denmark) Merits, Judgment [1969] ICJ Rep 3, the ICJ refused to apply the provisions of Article 6 of the 1958 Geneva Convention on the continental shelf as a rule of customary law. It hence focused on defining the legal principles that should govern the delimitation of the continental shelf between the two States. It nonetheless had a more marked attitude in the maritime delimitation case in the region located between Greenland and Jan Mayen (Denmark v Norway) [1993] ICJ Rep 61 [51]: 'For the delimitation of the continental shelf ... even if customary law on the continental shelf was to be applied instead of Article 6 of the 1958 Convention as developed in the jurisprudence'. There is the impression that customary law was hence ousted in favour of maritime delimitation law.

${ }^{3}$ Proceedings instituted in the dispute concerning the maritime boundary between Bangladesh and Myanmar in the Bay of Bengal, ITLOS/Press 140 (16 December 2009).
} 
International courts aided in developing what can now be referred to as maritime delimitation law, which we will endeavour to present in the form of an instruction manual or a notice on handling a maritime delimitation case. We will examine the applicable law (2), delimitation principles (3) and then the delimitation of the maritime border (4). We will lastly study the consequences of the delimitation method on the spatial distribution of State jurisdictions with respect to their rights and obligations including in the grey area (5).

\section{The applicable law}

The review commences with the presentation of the overall geographical setting; in other words, the maritime area within which delimitation should be determined; this area can be illustrated on a map. ${ }^{4}$ The judge may then recall the origin and evolution of the dispute, as indicated on the documents presented by the parties, ${ }^{5}$ prior to addressing the applicable law.

It is developed out of international custom and treaties, for instance, the Conventions on the law of the sea concluded in Geneva (Geneva Conventions) on 29 April 1958 and the UNCLOS on 10 December 1982. Articles 15, 74 and 83 of the UNCLOS relate, respectively, to the delimitation of the territorial sea, the EEZ and the continental shelf. ${ }^{6}$

The review of the jurisdiction clause, regardless of whether it is an arbitration clause or the application itself, allows the judge to determine the conditions of referral to the court and verify if these were met at the time the documents instituting the proceedings were submitted, thereby authorizing the judge to be seized of the case.

\footnotetext{
${ }^{4}$ See, for example, Maritime delimitation in the Black Sea (Romania v Ukraine) Judgment [2009] ICJ Rep 69.

5 See, Delimitation of the Maritime Boundary between Guinea and Guinea-Bissau, 19 RIAA 149-196 (14 February 1985) [18, 24].

${ }^{6}$ Article 15 of the Convention stipulates: Where the coasts of two States are opposite or adjacent to each other, neither of the two States is entitled, failing agreement between them to the contrary, to extend its territorial sea beyond the median line every point of which is equidistant from the nearest points on the baselines from which the breadth of the territorial seas of each of the two States is measured. The above provision does not apply, however, where it is necessary by reason of historic title or other special circumstances to delimit the territorial seas of the two States in a way which is at variance therewith. Articles 74 and 83 of the Convention are similarly worded and provide that: (1) The delimitation of the exclusive economic zone [continental shelf] between States with opposite or adjacent coasts shall be effected by agreement on the basis of international law, as referred to in Article 38 of the Statute of the International Court of Justice, in order to achieve an equitable solution. (2) If no agreement can be reached within a reasonable period of time, the States concerned shall resort to the procedures provided for in Part XV. (3) Pending agreement as provided for in paragraph 1, the States concerned, in a spirit of understanding and cooperation, shall make every effort to enter into provisional arrangements of a practical nature and, during this transitional period, not to jeopardize or hamper the reaching of the final agreement. Such arrangements shall be without prejudice to the final delimitation. (4) Where there is an agreement in force between the States concerned, questions relating to the delimitation of the exclusive economic zone [continental shelf] shall be determined in accordance with the provisions of that agreement. The UNCLOS, 1833 UNTS 3 (1982).
} 


\section{Principles of delimitation}

The maritime delimitation that the judge will carry out shall rely on the determination of the relevant coasts and the relevant maritime zones of each party.

\subsection{The relevant coasts}

Relevant coasts are crucial in the delimitation exercise. They are the basis of a State's entitlement to the areas to be delimited. As indicated by the ICJ, the title of a State to the continental shelf and to the EEZ is based on the principle that the land dominates the sea through the projection of the coasts or the coastal fronts. ${ }^{7}$ The land is the legal source of the power which a State may exercise over territorial extensions to seaward. ${ }^{8}$ Moreover, the coast of the territory of the State is the decisive factor for title to submarine areas adjacent to it. ${ }^{9}$ It is therefore important to determine the relevant coasts of each party to the case, which confer legal entitlement of countries to the continental shelf and the EEZ, i.e., those whose projections overlap, because the purpose of delimitation is to resolve the issue of overlapping claims by drawing a line of separation between the maritime areas concerned.

As explained by the ICJ, ${ }^{10}$ the role of relevant coasts can have two different though closely related legal aspects in relation to the delimitation of the continental shelf and the EEZ. First, it is necessary to identify the relevant coasts in order to determine what constitutes in the specific context of a case the overlapping claims to these zones. Second, the relevant coasts need to be ascertained in order to check, in the third and final stage of the delimitation process, whether any

\footnotetext{
${ }^{7}$ Maritime delimitation in the Black Sea, supra note 4, 89 [77].

8 North Sea Continental Shelf Case [1969] ICJ Rep 51 [96].

${ }^{9}$ See the subject matter of delimitation disputes are indeed many: in the Grisbadarna Case (Norway v Sweden) [1909] 11 RAA $147 \mathrm{ff}$, the arbitral award of 14 March 1908 stipulates: 'Article 3: The Arbitral Tribunal shall decide whether the boundary line should be considered, either wholly or in part, as fixed by the Boundary Treaty of 1661 with the map annexed thereto, and in what manner the line thus established should be drawn; that in so far as the boundary line shall not be considered as fixed by that Treaty and map, the Tribunal shall determine the boundary line'; first, the outstanding dispute between the two Emirates of Dubai and Sharjah concerning the demarcation of the boundaries between them shall be referred to arbitration in the Continental Shelf Case (Tunisia/Libya) [1982] ICJ Rep $18 \mathrm{ff}$ article one of the special agreement of 10 June 1977 stipulates: 'The Court is requested to render its judgement in the following matter: What principles and rules of international law may be applied for the delimitation of the area of the continental shelf appertaining to the Socialist People's Libyan Arab Jamahiriya and to the area of the continental shelf appertaining to the Republic of Tunisia and the Court shall take its decision according to equitable principles and the relevant circumstances which characterize the area as well as the new accepted trends in the Third Conference on the Law of the Sea.'
}

${ }^{10}$ Romania v Ukraine, supra note 4, 89 [78]. 
disproportionality exists in the ratios of the coastal length of each State and the maritime areas falling either side of the delimitation line. ${ }^{11}$ Any part of the coast of one Party which, because of its geographic situation, cannot overlap with the extension of the coast of the other is to be excluded from further consideration by the Court. ${ }^{12}$ After ascertaining the relevant coasts of each party, the judge establishes the ratio between the lengths of the respective coasts of each State and then verifies if there is any disproportionality between the ratio of the lengths of the coasts of each party and that of maritime areas on either side of the delimitation line. ${ }^{13}$

\subsection{The relevant maritime zone}

Seaward projections of relevant coasts of the coastal State and the encroachment effect of these projections on those at sea of the other coastal State determine maritime delimitation. This means therefore that the delimitation exercise only takes into account coasts that generate overlapping titles. It is for this reason that the utility of the

11 North Sea Continental Shelf Case, supra note 8, 51 [96].

12 Tunisia $v$ Libya, supra note 9, [1982] ICJ Rep 61 [75].

13 The ICJ has often faced difficulties to determine relevant coasts. In the Case Concerning the Continental Shelf (Libyan Arab Jamahiriya v Nalta) [1985] ICJ Rep [74] states: 'In the view of the Court, there is no reason of principle why the test of proportionality, more or less in the form in which it was used in the Tunisia/ Libya case, namely the identification of "relevant coasts", the identification of "relevant areas" of continental shelf, the calculation of the mathematical ratios of the lengths of the coasts and the areas of shelf attributed, and finally the comparison of such ratios, should not be employed to verify the equity of a delimitation between opposite coasts, just as well as between adjacent coasts. However, there may well in such a case be practical difficulties which render it inappropriate in that form. These difficulties are particularly evident in the present case where, in the first place, the geographical context is such that the identification of the relevant coasts and the relevant areas is so much at large that virtually any variant could be chosen, leading to widely different results, and in the second place the area to which the judgment will in fact apply is limited by reason of the existence of claims of third States. To apply the proportionality test simply to the areas within these limits would be unrealistic; ....' However, the primacy of coastal geography in terms of delimitation is settled jurisprudence: 'It is ... necessary to examine closely the geographical configuration of the coastlines of the countries whose continental shelves are to be delimited' North Sea Case, supra note 1, [1969] ICJ Rep [96]; ' . . the method of delimitation which it adopts for the Atlantic region must be one that has relation to the coasts of the Parties actually abutting on the continental shelf of that region.' 'The coast of each of the Parties ... constitutes the starting line from which one has to set out in order to ascertain how far the submarine areas appertaining to each of them extend in a seaward direction, as well as in relation to neighbouring States situated either in an adjacent or opposite position,' Tunisia v. Libya, supra note 9, [1982] ICJ Rep [74]; 'The delimitation line to be drawn in a given area will depend upon the coastal configuration,' Gulf of Maine case. In the case concerning the Gulf of Maine area (Canada v United States of America) [1984] ICJ Rep $246 \mathrm{ff}$, the special agreement of 29 March 1979 stipulates in its article 2: the Chamber is requested to decide, in accordance with the principles and rules of international law applicable in the matter as between the Parties, the following question: What is the course of the single maritime boundary that divides the continental shelf and fisheries zones of Canada and the United States of America [...]. 2) The Chamber is requested to describe the course of the maritime boundary in terms of geodetic lines connecting geographic coordinates of points. The Chamber is also requested for illustrative purposes only to depict the course of the boundary on ... chart ... [1984] ICJ Rep [205]. 
notion of relevant maritime zone is often challenged. The ICJ ${ }^{14}$ sought to justify the use of this notion. It observed that the legal concept of the "relevant area" has to be taken into account as part of the methodology of maritime delimitation.

In the first place, depending on the configuration of the relevant coasts in the general geographical context and the methods for the construction of their seaward projections, the relevant area may include certain maritime spaces and exclude others which are not germane to the case in hand. Secondly, the relevant area is pertinent to checking disproportionality. This will be done as the final phase of the methodology. The purpose of delimitation is not to apportion equal shares of the area or indeed proportional shares. The test of disproportionality is not in itself a method of delimitation. It is rather a means of checking whether the delimitation line arrived at by other means needs adjustment because of a significant disproportionality in the ratios between the maritime areas which would fall to one party or other by virtue of the delimitation line arrived at by other means, and the lengths of their respective coasts.

The Court further observes that ${ }^{15}$ for the purposes of this final exercise in the delimitation process the calculation of the relevant area does not purport to be precise and is approximate. The object of delimitation is to achieve a delimitation that is equitable, not an equal apportionment of maritime areas. ${ }^{16}$

The relevant maritime zone covers the entire area of coastal extensions of litigating States. These projections may overlap those of third-party States. ${ }^{17}$

After establishing the relevant maritime zone, the judge will then proceed with the maritime delimitation requested by the litigating

\footnotetext{
${ }^{14}$ Romania v Ukraine, supra note 4, 99 [110].

15 Ibid [111].
}

${ }^{16}$ Germany v Denmark, supra note 2, 21-22 [18], the Court states: '[...] having regard both to the language of the Special Agreements and to more general considerations of law relating to the regime of the continental shelf, its task in the present proceedings relates essentially to the delimitation and not the apportionment of the areas concerned, or their division into converging sectors. Delimitation is a process which involves establishing the boundaries of an area already, in principle, appertaining to the coastal State and not the determination de novo of such an area. Delimitation in an equitable manner is one thing, but not the same thing as awarding a just and equitable share of a previously undelimited area, even though in a number of cases the results may be comparable, or even identical.' In the delimitation case (Greenland v Jan Mayen), supra note 2, [64], the Court states: '[...] Thus the law does not require a delimitation based upon an endeavour to share out an area of overlap on the basis of comparative figures for the length of the coastal fronts and the areas generated by them. The task of a tribunal is to define the boundary line between the areas under the maritime jurisdiction of two States; the sharing-out of the area is therefore the consequence of the delimitation, not vice versa.'

17 Romania v Ukraine, supra note 4, 100 [112], the Court notes that the delimitation will occur within the enclosed Black Sea, with Romania being both adjacent to, and opposite Ukraine, and with Bulgaria and Turkey lying to the south. It will stay north of any area where third-party interests could become involved. 
parties. To this end, he shall make use of the applicable rules on delimitation that emerge from the jurisprudence in the absence of rules in the UNCLOS.

\section{Delimitation of the maritime boundary}

\subsection{The method of delimitation}

It is outlined by the $\mathrm{ICJ}^{18}$ in the Case Concerning the Continental shelf (Libya/Malta) in which it states: 'In applying the equitable principles thus elicited, within the limits defined above, and in the light of the relevant circumstances, the Court intends to proceed by stages; thus, it will first make a provisional delimitation by using a criterion and a method both of which are clearly destined to play an important role in producing the final result; it will then examine this provisional solution in the light of the requirements derived from other criteria, which may call for a correction of this initial result.'

The provisional delimitation line is determined, using methods that are geometrically objective and also appropriate for the geography of the area in which the delimitation is to take place. So far as delimitation between adjacent coasts is concerned, an equidistance line will be drawn unless there are compelling reasons that make this unfeasible in the particular case. ${ }^{19}$ So far as opposite coasts are concerned, the provisional delimitation line will consist of a median line between the two coasts. No legal consequences flow from the use of the terms "median line" and "equidistance line" since the method of delimitation is the same for both. ${ }^{20}$

Equidistance and median lines are to be constructed from the most appropriate points on the coasts of the two States concerned, with particular attention being paid to those protuberant coastal points situated nearest to the area to the delimited.

The Court considers therefore the extent to which the Court may, when constructing a single-purpose delimitation line, deviate from the base points selected by the Parties for their territorial seas. When construction of a provisional equidistance line between adjacent States

\footnotetext{
18 Libya $v$ Malta, supra note 13, 46 [60].

19 Case Concerning the Territorial and Maritime Dispute in the Caribbean Sea (Nicaragua v Honduras), [2007] ICJ Rep 745 [281], it is stated: ' ..., the Court finds itself within the exception provided for in Article 15 of UNCLOS, namely facing special circumstances in which it cannot apply the equidistance principle. At the same time equidistance remains the general rule.'

${ }^{20}$ This is stated by the ICJ in the aforementioned Black Sea Case, supra note 4, 101 [116].
} 
is called for, the Court will have in mind considerations relating to both Parties' coastlines when choosing its own base points for this purpose. The line thus adopted is heavily dependent on the physical geography and the most seaward points of the two coasts. In keeping with its settled jurisprudence on maritime delimitation, the first stage of the Court's approach is to establish the provisional equidistance line. At this stage, the judge pays no heed to any relevant circumstances, and the line is drawn in accordance with strictly geometric criteria on the basis of objective data. ${ }^{21}$

Based on the coastal configuration of litigating States, the provisional line may vary: an equidistance line between adjacent coasts and a median line between opposite coasts, for example. Given that the course of the final line should result in an equitable solution, ${ }^{22}$ the Court will at the second stage consider whether there are factors calling for the adjustment or shifting of the provisional equidistance line in order to achieve an equitable result. ${ }^{23}$ This is the second part of the delimitation exercise to which the Court will turn, having first established the provisional equidistance line.

In the third stage, the Court will verify that the line does not, as it stands, lead to an inequitable result by reason of any marked disproportion between the ratio of the respective coastal lengths and the ratio between the relevant maritime area of each State by reference to the delimitation line. A final check for an equitable outcome entails a confirmation that no great disproportionality of maritime areas is evident by comparison to the ratio of coastal lengths. ${ }^{24}$

\footnotetext{
21 Ibid 101 [118].
}

22 In compliance with the first paragraphs of Articles 74 and 83 of the UNCLOS.

${ }^{23}$ Case Concerning the Land and Maritime Boundary (Cameroon and Nigeria, Equatorial Guinea intervening) [2002] ICJ Rep <http://www.icjcij.org/docket/files/94/7453.pdf>. On 29 March 1994, the Government of Cameroon filed an application in the Registry of the ICJ in which it observed that 'delimitation [of the maritime boundary between the two States] has remained a partial one and, despite many attempts to complete it, the two parties have been unable to do so.' It consequently requested the court, 'In order to avoid further incidents between the two countries, $[\ldots]$ to determine the course of the maritime boundary between the two States beyond the line fixed in 1975.' In the Case between Cameroon and Nigeria, the ICJ states in [288]: "The Court has on various occasions made it clear what the applicable criteria, principles and rules of delimitation are when a line covering several zones of coincident jurisdictions is to be determined. They are expressed in the so-called equitable principles/relevant circumstances method. This method, which is very similar to the equidistance/special circumstances method applicable in delimitation of the territorial sea, involves first drawing an equidistance line, then considering whether there are factors calling for the adjustment or shifting of that line in order to achieve an "equitable result." See also the aforementioned case Nicaragua $v$ Honduras, supra note 19, 741 [271].

${ }^{24}$ Romania v Ukraine, supra note 4, 103 [122]: 'This is not to suggest that these respective areas should be proportionate to coastal lengths: as the Court has said "the sharing out of the area is therefore the consequence of the delimitation, not vice versa". Maritime Delimitation in the Area between Greenland and Jan Mayen (Denmark v Norway), Judgment, [1993] ICJ Rep 67 [64] 


\subsection{The provisional equidistance line}

This includes two key stages: selection of base points and consequently the construction of the line itself. The geography of the area to be delimited plays an important role in the selection of base points. The judge will therefore always describe the general geographical context when called upon to carry out maritime delimitation.

In the case of the Black Sea delimitation, the Court had to indicate the conclusions drawn from the fact that the dispute related to both adjacent and opposite coasts. The Court will identify the appropriate points on the Parties' relevant coast or coasts which mark a significant change in the direction of the coast, in such a way that the geometrical figure formed by the line connecting all these points reflects the general direction of the coastlines. The points thus selected on each coast will have an effect on the provisional equidistance line that takes due account of the geography. ${ }^{25}$

According to the Court, ${ }^{26}$ the geography shows that the capacity of the coasts to generate overlapping titles indicates the existence of two areas: in one case, the coasts are adjacent; in the other, they are opposite. In practice, the first conclusion which the Court draws from this is that, on the Romanian coast, the significant base points from which the equidistance line and the median line must be established are the same, since this coast is both adjacent and opposite to the Ukrainian coast. The second conclusion is that, as the Ukrainian coast consists of two portions-one adjacent to the Romanian coast, the other opposite to it-the base points to take into account must be defined separately, according to whether the adjacent or opposite portion is concerned. The third conclusion is the identification of a turning-point on the equidistance line where the effects of adjacency give way to those of the coasts on the opposite side, resulting in a change in the direction of the line. Lastly, the Court will need to consider the relevance or otherwise of Serpents' Island in terms of the choice of base points.

After describing the views of Parties on base points to be taken into consideration in order to draw the provisional equidistance line between adjacent coasts of the two parties, the Court examined the question of whether the base points to be used could be the same as those selected by each State to determine the outer limit of its territorial

\footnotetext{
25 Ibid, 105 [127].

26 Ibid [128].
} 
sea. In this respect, the Court observed ${ }^{27}$ that the geometrical nature of the first stage of the delimitation exercise leads it to use as base points those which the geography of the coast identifies as a physical reality at the time of the delimitation. That geographical reality covers not only the physical elements produced by geodynamics and the movements of the sea, but also any other material factors that are present.

The Court upholds the dual principle of baselines and base points. It appears that the base points and baselines for the purpose of delimitation are independent of those that serve to measure the breadth of the territorial sea and other maritime jurisdictions. The Court $^{28}$ observes that the issue of determining the baseline for the purpose of measuring the breadth of the continental shelf and the EEZ and the issue of identifying base points for drawing an equidistance/median line for the purpose of delimiting the continental shelf and the EEZ between adjacent/opposite States are two different issues.

In the first case, the coastal State may determine the relevant base points in compliance with provisions of the UNCLOS. ${ }^{29}$ This is, however, an exercise that always has a point of international relevance. ${ }^{30}$ In the second case relating to the delimitation of maritime zones between two States or more, the Court cannot rely on the selection of base points by one of the parties. When called upon to delimit the continental shelf and EEZ, the Court shall use base points in reference to the physical geography of relevant coasts.

After identifying the base points on the coastlines of the two parties, the Court will trace the provisional equidistance line based on those points, which will be identical to the provisional median line. This line will be confronted with the relevant circumstances in order to achieve an equitable result.

\subsection{The relevant circumstances}

When the provisional equidistance line is drawn, the judge considers whether any factors calling for an adjustment or displacement of this line to achieve an equitable result. ${ }^{31}$ These factors, considered as

\footnotetext{
27 Ibid [131].

28 Ibid [137].

29 These include articles 7, 9, 10, 12 and 15 of the UNCLOS.

30 Fishries case (United Kingdom v Norway) [1952] ICJ Rep 116 [132].

31 This principle was constructed over a long period from 1969 Case Concerning the North Sea Continental Shelf, Tunisia v Libya (1982), Case Concerning the Gulf of Maine (1984) and Libya v Malta (1985) with the (contd.)
} 
relevant circumstances, ${ }^{32}$ allow the judge to ensure that the provisional equidistance line that has been drawn based on the geometrical method from base points identified on the Parties' coastlines is not, in the light of the special circumstances, perceived as inequitable. If such was the case, the judge would adjust the line in order to reach an equitable solution. ${ }^{33}$

Regarding applicable rules, the Court observes that the respective length of coasts can play no role in identifying the equidistance line which has been provisionally established. Delimitation is a function which is different from the apportionment of resources or areas. ${ }^{34}$ There is no principle of proportionality as such which bears on the initial establishment of the provisional equidistance line.

Where disparities in the lengths of coasts are particularly marked, the Court may choose to treat that fact of geography as a relevant circumstance that would require some adjustments to the provisional equidistance line to be made.

The Court acknowledged that 'a substantial difference in the lengths of the parties' respective coastlines may be a factor to be taken into consideration in order to adjust or shift the provisional delimitation line. ${ }^{35}$ The Court found that the disparity between the lengths of the coasts of Jan Mayen and Greenland (approximately 1:9) constituted a "special circumstance" requiring modification of the provisional median line, by moving it closer to the coast of Jan Mayen, to avoid inequitable results for both the continental shelf and the fisheries zone. ${ }^{36}$

In the Case Concerning the Delimitation of the Maritime Boundary in the Gulf of Maine area (Canada v. United States of America), the Court examining 'the equitable criteria that may be taken into consideration for an international maritime delimitation' stated:

[T] he fact that to take into account the extent of the respective coasts of the Parties concerned does not in itself constitute either a criterion serving as a direct basis for a delimitation, or a method that can be used to implement such

\footnotetext{
famous statement of principle of the Court: 'but in any event the baselines as determined by coastal States are not per se identical with the points chosen on a coast to make it possible to calculate the area of continental shelf appertaining to that State. In this case, the equitableness of an equidistance line depends on whether the precaution is taken of eliminating the disproportionate effect of certain "islets, rocks and minor coastal projections".' Libyan Arab Jamahiriya v Malta, supra note 13, 48 [64].

32 Cameroon v Nigeria, supra note 23, 441 [288].

33 North Sea Case, supra note 2, 53 [53].

34 As provided for in paragraph 1 of articles 74 and 83 of the UNCLOS.

35 North Sea Continental Shelf, supra note 2, 22 [18].

36 Cameroon v Nigeria, supra note 23, 446 [301].
} 
delimitation. The Chamber recognizes that this concept is put forward mainly as a means of checking whether a provisional delimitation established initially on the basis of other criteria, and by the use of a method which has nothing to do with that concept, can or cannot be considered satisfactory in relation to certain geographical features of the specific case, and whether it is reasonable or otherwise to correct it accordingly. The Chamber's views on this subject may be summed up by observing that a maritime delimitation can certainly not be established by a direct division of the area in dispute proportional to the respective lengths of the coasts belonging to the parties in the relevant area, but it is equally certain that a substantial disproportion to the lengths of those coasts that resulted from a delimitation effected on a different basis would constitute a circumstance calling for an appropriate correction. ${ }^{37}$

The question of special circumstances to be taken into consideration will be dealt with at a later stage by the Court. According to the Court, ${ }^{38}$ although there may be no legal limit to the considerations which States may take account of, this can hardly be true for a court applying equitable procedures. For a judge, although there is assuredly no exhaustive list of considerations, it is evident that only those that are pertinent to the institution of the continental shelf as it has developed within the law, and to the application of equitable principles to its delimitation, will qualify for inclusion. Otherwise, the legal concept of continental shelf could itself be fundamentally changed by the introduction of considerations strange to its nature.

In fact, the judge will only focus on circumstances relating to the legal title of the State on disputed maritime areas and which will allow him to draw a delimitation line that is acceptable and equitable for parties. After taking into consideration, or not, one or more relevant circumstances likely to result in the adjustment or shifting of the provisional delimitation line, the judge will determine and draw what

\footnotetext{
${ }^{37}$ Maritime Delimitation (Greenland and Jan Mayen), supra note 16, the Court observed that it should however be made clear that taking account of the disparity of coastal lengths does not mean a direct and mathematical application of the relationship between the length of the coastal front of eastern Greenland and that of Jan Mayen,' [69]; In the Case between Libya and Malta, the Court observed: 'If such a use of proportionality were right, it is difficult indeed to see what room would be left for any other consideration; for it would be at once the principle of entitlement to continental shelf rights and also the method of putting that principle into operation. Its weakness as a basis of argument, however, is that the use of proportionality as a method in its own right is wanting of support in the practice of States, in the public expression of their views at (in particular) the Third United Nations Conference on the Law of the Sea, or in the jurisprudence,' supra note 13, 45 [58]. In the same case, the Court considered that the difference between the lengths of the relevant coasts of Malta and Libya (1:8 ratio) was 'so great as to justify the adjustment of the median line' and that 'the degree of such adjustment does not depend upon a mathematical operation and remains to be examined'; ibid., 50 [68].

38 Case Concerning the Gulf of Maine, supra note 13, 323 [185].
} 
will become the final delimitation line. All that remains is to verify the absence of disproportionality for the judge to fully accomplish his task.

\subsection{Verification of the absence of disproportionality}

The judge will now turn to check that the result thus far arrived at, so far as the envisaged delimitation line is concerned, should not lead to any significant disproportionality by reference to the respective coastal lengths and the apportionment of areas that ensue. The ICJ ${ }^{39}$ recommends the attitude to be adopted. Views contained in the judgment in the case concerning the delimitation of continental shelf between the United Kingdom and the French Republic are decisive. ${ }^{40}$ In examining the concepts of "proportionality" and "reasonable evaluation of natural features," the Tribunal stated:

$[\mathrm{P}]$ articular configurations of the coast or individual geographical features may, under certain conditions, distort the course of the boundary, and thus affect the attribution of continental shelf to each State, which would otherwise be indicated by the general configuration of their coasts. The concept of "proportionality" merely expresses the criterion or factor by which it may be determined whether such a distortion results in an inequitable delimitation of the continental shelf as between the coastal States concerned ... It is disproportion rather than any general principle of proportionality which is the relevant criterion or factor ... there can never be a question of completely refashioning nature ... it is rather a question of remedying the disproportionality and inequitable effects produced by particular geographical configurations or features ... Proportionality, therefore is to be used as a criterion or factor relevant in evaluating the equities of certain geographical situations, not as a general principle providing an independent source of rights to areas of continental shelf ... proportionality is not in itself a source of title $[\ldots]$, but is rather a criterion for evaluating the equities of certain geographical situations ... The element of proportionality ..., its role being rather that of a criterion to assess the distorting effects of particular geographical features and the extent of the resulting inequity. ${ }^{41}$

Checking the absence of disproportionality can only be approximate. Diverse techniques have in the past been used for assessing coastal

\footnotetext{
39 Libya v Malta, supra note 13, [48].

40 North Sea Continent Shelf, supra note 2, [98]: '...to be taken account of [...] the element of a reasonable degree of proportionality which a delimitation effected according to equitable principles ought to bring about between the extent of the continental shelf appertaining to the States concerned and the lengths of their respective coastlines.'

${ }^{41}$ Delimitation of the Continental Shelf between the United Kingdom of Great Britain and Northern Ireland, and the French Republic, XVIII RIAA 189 and ff., [100, 101, 246, 250]; see also Guinea v. Guinea-Bissau, XIX RIAA 183-184 [94-95].
} 
lengths, with no clear requirements of international law having been shown as to whether the real coastline should be followed, or baselines used, or whether or not coasts relating to internal waters should be excluded ${ }^{42}$ each maritime delimitation case is a "unicum." 43

After half a century, maritime delimitation has reached maturity with its three stages. The first stage, which is the starting point, consists of drawing a provisional equidistance line. The second stage consists of ensuring that this line produces an equitable result in which case the provisional line becomes final. ${ }^{44}$ However, if the provisional equidistance line does not produce an equitable result, the judge shall adjust or shift this line based on the relevant circumstances of the case; this is the third and final stage. This three-stage paradigm will render great service to the judge in his search for a solution to the maritime delimitation dispute by offering stability and predictability. We shall now discuss what is referred to as the "Grey area", the "Alta mar" or the "Outer triangle".

\section{The grey area}

The Grey Area ${ }^{45}$ is an area lying within 200 miles from the coast of one state, but beyond a maritime boundary with another state. One state is excluded from

42 Black Sea Delimitation, supra note 4, 129 [212].

43 Ibid., [213].

44 [1984] ICJ Rep 290 [81].

45 In the Reply of the United States of America in the Case Concerning the Gulf of Maine, Mr. Colson explained: 'The final preliminary issue of geographical significance with which we will deal—and then set aside-is the matter of the so-called grey area.

[...] Let us turn now to the four reasons we would give to suggest that the grey area is not a matter that should concern the Chamber in this case. First, the grey area issue has been known for some time and to our knowledge it has never deterred States from applying a method or methods other than the equidistance method when it was equitable to do so. Second, the three United Nations Law of the Sea Conferences have paid no heed to the grey area issue. Third, State practice has not been concerned with this issue. And, fourth, the Parties have provided a means for dealing with the issue in the Special Agreement. [...] Figure 109 of our presentation shows two charts-one of the Chile-Peru maritime boundary and the other of the Peru-Ecuador maritime boundary. [...] In the case of the boundary between Chile and Peru, the grey area created by the boundary measure approximately 7,800 square nautical miles. In the case of the boundary between Peru and Ecuador it is smaller, measuring about 400 square nautical miles [...]. We would also point out that areas of various sizes exist wordwide, including such negotiated delimitations as those between Kenya-Tanzania, Colombia-Ecuador, The Gambia-Senegal, Guinea-Bissau-Senegal, the northern boundary between Portugal and Spain, and Brazil-Urugauy.

Accordingly, the fact that a grey area would exist were the United States line or others through the Northeast Channel to prevail, is not an unusual circumstance such as to warrant the Chamber's concern. The grey area in this case, which would be created by the United States line, is approximately 5700 square nautical miles,' ICJ Oral Proceedings, Gulf of Maine Case (Canada/United States of America), vol. VII, 217-220. Judgment was delivered on 12 October 1984 by the Chamber formed pursuant to the Court order of 20 January 1982. (Delimitation of the Maritime Boundary in the Gulf of Maine Area, Judgment, [1984] ICJ Rep 246). 
exercising jurisdiction in this area because it lies beyond the maritime boundary, and the other state is excluded from exercising 200-miles-zone jurisdiction because the grey area on its side of the boundary lies beyond 200 miles from its coast. The possibility of creating a grey area stems from the fact that there is a discrepancy between entitlement to the EEZ and the principle applicable to its delimitation. Entitlement to this zone is solely based on distance from the coast, but its delimitation between states can be effected on the basis of principles other than distance from the coast. This results in a line which reaches the outer limit of the EEZ at a point which is non-equidistant from the coast of the states concerned. If such a line is applied to limit the maritime zones of both states involved, a grey area is created. ${ }^{46}$

The expression "grey area" reveals the uncertainties of its legal status. The grey area refers to a geographic area that is the focus of overlapping claims in the EEZ, the continental shelf or the extended continental shelf of two or more coastal States. ${ }^{47}$

Consequently, the Grey area poses numerous and complex legal issues relating to applicable principles for delimitation within and beyond the 200-nautical-mile limit, the relation between rights and entitlements to the EEZ and the continental shelf, and in particular, the possibility or not to create such an area in determining ab initio the boundary, the EEZ limits or the territorial sea. ${ }^{48}$

\subsection{Entitlement and delimitation}

The creation of a grey area in determining boundaries relating to the EEZ or the territorial sea depends on the existing relation between the entitlement and the delimitation of maritime areas. Entitlement to these areas is dependent on the criterion of distance measured from the coast with the notable exception of historical entitlements.

${ }^{46}$ AG Oude Elferink, Does Undisputed Title to a Maritime Zone Always Exclude Its Delimitation: The Grey Area Issue, 13(2) Intl J Marine and Coastal L (1998) 143-192, 143.

47 See, Shaun Lin and Clive Schofield, Lessons from the Bay of Bengal ITLOS Case: Stepping Offshore for a "Deeper" Maritime Political Geography, 180(3) The Geographical J (2014) 260-264, 260, where the authors explain: 'The ITLOS delimited a maritime boundary with respect to multiple distinct maritime jurisdictional zones (territorial sea, exclusive economic zone and continental shelf) between Bangladesh and Myanmar (Bay of Bengal Case). ITLOS did not however, wholly resolve the issues of marine governance that the two states face in the Bay of Bengal, leaving a number of complex and potentially problematic issues outstanding, including the unique creation of what was termed a "grey area", the governance arrangements for which are open to debate.'

48 In the Case Concerning the Gulf of Maine, supra note 13, Canada suggests in its Counter-Memorial, 239 that the Grey area could be eliminated by awarding it to the State holding the undisputed title to the said area, with three possible consequences: '(1) A boundary which intersects the 200-nautical-mile limits in the vicinity of the equidistance line, eliminating or diminishing the grey area; (2) If the single maritime boundary principle is maintained, one party will have continental shelf jurisdiction in the grey area and neither party will have fishery zone or EEZ jurisdiction; and (3) If overlapping jurisdictions are accepted, one party will have continental shelf jurisdiction and the other jurisdiction over the water column.' The latter was selected in the jurisprudence of the Bay of Bengal. 
However, delimitation of the EEZ or continental shelf between States with adjacent or opposite coasts may be carried out based on principles and criteria other than that of the distance measured from the coast.

In the case concerning delimitation of the maritime boundary in the Bay of Bengal, ${ }^{49}$ the ITLOS applied the three-stage paradigm. ${ }^{50}$ It determined the method of delimitation, drew the provisional equidistance line and verified the absence of disproportionality. It decided that the method to be used for delimiting the EEZ and the continental shelf between Bangladesh and Myanmar was the relevant equidistance/circumstances method. ${ }^{51}$

As reiterated by the Tribunal, ${ }^{52}$ delimitation presupposes an area of overlapping entitlements. Entitlement and delimitation are two distinct concepts yet they are interrelated. Parties also recognize the interrelationship between entitlement and delimitation. Bangladesh states: 'The Tribunal must answer this question before it can delimit the shelf: does either Party have an entitlement to a continental shelf beyond 200 nautical miles?' Likewise, Myanmar observes that 'the determination of the entitlements of both States to a continental shelf beyond 200 nautical miles and their respective extent is a prerequisite for any delimitation.'

In the present case, the Parties have made claims to the continental shelf beyond 200 nautical miles which overlap. Part of this area is also claimed by India. Each Party denies the other's entitlement to the continental shelf beyond 200 nautical miles. Furthermore, Myanmar argues that the Tribunal cannot address the issue of the entitlement of either Bangladesh or Myanmar to a continental shelf beyond $200 \mathrm{~nm}$, as this is an issue that lies solely within the competence of the Commission on the Limits of the Continental Shelf (CLCS), not of the Tribunal.

The delimitation of the continental shelf beyond 200 nautical miles gives rise to a grey area located beyond 200 nautical miles from the coast of Bangladesh but within 200 nautical miles from the coast of Myanmar, yet on the Bangladesh side of the delimitation line. The Parties differ on the status and treatment of the Grey area.

\footnotetext{
49 Dispute Relating to the Delimitation of the Maritime Boundary in the Bay of Bengal (Bangladesh v Myanmar) ITLOS, Case no. 16, Judgment of 14 March 2012 [177-340]; Bay of Bengal Maritime Boundary Arbitration (Bangladesh v India)<http://www.pca-cpa.org/showpage.asp?pag_id=1376>; Maritime Dispute (Peru v Chile) [2014] <www.icj-cij.org/docket/files/137/17930.pdf>; Territorial and Maritime Dispute (Nicaragua v Colombia) [2012] ICJ Rep 624.

50 Ibid [35-60].

51 Bangladesh v Myanmar, ibid [23].

52 Ibid [397-398].
} 
Myanmar does not dispute that, 'as a matter of principle, the delimitation of the continental shelf, including the shelf beyond 200 nautical miles, could fall within the jurisdiction of the Tribunal. ${ }^{53}$

Myanmar asserts in its Counter-Memorial that, as a general matter, the question of the Tribunal's jurisdiction to delimit the continental shelf beyond 200 nautical miles should not arise in this case, because the delimitation line should terminate well before reaching the 200-nauticalmile limit from the baselines from which the breadth of the territorial sea is measured. ${ }^{54}$

Myanmar adds: 'Even if the Tribunal were to decide that there could be a single maritime boundary beyond 200 nautical miles (quod non), the Tribunal would still not have jurisdiction to determine this line because any judicial pronouncement on these issues might prejudice the rights of third parties and also those relating to the international seabed area. ${ }^{.55}$

Myanmar argues: 'As long as the outer limit of the continental shelf has not been established on the basis of the recommendations of the CLCS, the Tribunal, as a court of law, cannot determine the line of delimitation on a hypothetical basis without knowing what the outer limits are. ${ }^{56}$ It maintains:

A review of a State's submission and the making of recommendations by the Commission on this submission is a necessary prerequisite for any determination of the outer limits of the continental shelf of a coastal State "on the basis of these recommendations" under article 76 (8) of UNCLOS and the area of continental shelf beyond 200 nautical miles to which a State is potentially entitled; this, in turn, is a necessary precondition to any judicial determination of the division of areas of overlapping sovereign rights to the natural resources of the continental shelf beyond 200 nautical miles. To reverse the process, ... to adjudicate with respect to rights the extent of which is unknown, would not only put this Tribunal at odds with other treaty bodies, but with the entire structure of the Convention and the system of international ocean governance. ${ }^{57}$

In support of its position, Myanmar cites the Arbitral Award in the Case concerning the Delimitation of Maritime Areas between Canada and France (St Pierre and Miquelon), which states: 'It is not possible for a tribunal to reach a decision by assuming hypothetically the eventuality that such

\footnotetext{
53 Counter-Memorial of Myanmar, in, Bangladesh v Myanmar, ibid [1.14].

54 Ibid [1.15].

55 Ibid [1.16].

56 Ibid [1.17].

57 Rejoinder of Myanmar [A.17].
} 
rights will in fact exist. ${ }^{58}$ In the view of the arbitral tribunal, any decision on delimiting the continental shelf beyond 200 nautical miles between France and Canada would have been based solely on hypothetical rights. Myanmar also cites the ICJ judgment in the Nicaragua v. Honduras case, asserting that the Court there declined to delimit the continental shelf beyond 200 nautical miles between Nicaragua and Honduras because the CLCS had not yet made recommendations to the two countries concerning their continental shelf beyond 200 nautical miles. The judgment cited by Myanmar to this effect states:

[...] It should also be noted in this regard that in no case may the line be interpreted as extending more than 200 nautical miles from the baselines from which the breadth of the territorial sea is measured; any claim of continental shelf rights beyond 200 miles must be in accordance with Article 76 of UNCLOS and reviewed by the CLCS established thereunder. ${ }^{59}$

Myanmar elaborated on its position during the oral proceedings, stating, inter alia, that in principle it did not question the Tribunal's jurisdiction. The two Parties did indeed accept the jurisdiction of the Tribunal on the same terms, in accordance with the provisions of article 287, paragraph 1 , of the Convention, for the 'settlement of [the] dispute ... relating to the delimitation of [the] maritime boundary between the two countries in the Bay of Bengal.' According to Myanmar, the only problem concerned the possibility that the Tribunal might exercise such jurisdiction to decide on the delimitation of the continental shelf beyond 200 nautical miles.

Myanmar further contended that, if the Tribunal 'nevertheless were to consider the Application admissible on this point-quod non-', it 'could not but defer judgment on this aspect of the matter until the Parties, in accordance with Article 76 of the Convention, have taken a position on the recommendations of the Commission concerning the existence of entitlements of the two Parties to the continental shelf beyond 200 [nautical miles] and, if such entitlements exist, on their ... extension' towards the outer limits of the continental shelf of the two countries. ${ }^{60}$

Bangladesh is of the view that the Convention expressly empowers the Tribunal to adjudicate disputes between States arising under articles

\footnotetext{
58 [1992] XXXI RIAA 293 [81].

59 Nicaragua v Honduras, supra note 19, 659, 759 [319].

${ }^{60}$ ITLOS/PV.11/11, 9, 18-23.
} 
76 and 83 , in regard to the delimitation of the continental shelf. As the Convention draws no distinction between jurisdiction over the inner part of the continental shelf, i.e., that part within 200 nautical miles, and the part further away, delimitation of the entire continental shelf is, according to Bangladesh, covered by article 83 , and the Tribunal plainly has jurisdiction to carry out delimitation beyond 200 nautical miles. ${ }^{61}$

Responding to Myanmar's argument that 'in any event, the question of delimiting the shelf beyond 200 [nautical miles] does not arise because the delimitation line terminates well before reaching the 200 [nautical mile] limit,' Bangladesh states that 'Myanmar's argument that Bangladesh has no continental shelf beyond 200 [nautical miles] is based instead on the proposition that once the area within 200 [nautical miles] is delimited, the terminus of Bangladesh's shelf falls short of the 200 nautical mile limit. ${ }^{62}$ Bangladesh contends ' $[t]$ his can only be a valid argument if the Tribunal first accepts Myanmar's arguments in favour of an equidistance line within 200 nautical miles. Such an outcome would require the Tribunal to disregard entirely the relevant circumstances relied upon by Bangladesh'.

With reference to Myanmar's argument regarding the rights of third parties, Bangladesh contends that a potential overlapping claim of a third State cannot deprive the Tribunal of jurisdiction to delimit the maritime boundary between two States that are subject to the jurisdiction of the Tribunal, because third States are not bound by the Tribunal's judgment and their rights are unaffected by it. Bangladesh points out that so far as third States are concerned, a delimitation judgment by the Tribunal is merely res inter alios acta and that this assurance is provided in article 33, paragraph 2, of the Statute of the Tribunal. ${ }^{64}$

Bangladesh also observes that Myanmar's contention 'with regard to the international seabed area disregards its own submission to the CLCS, which makes clear that the outer limits of the continental shelf vis-à-vis the international seabed are far removed from the maritime boundary with Bangladesh. ${ }^{65}$ Bangladesh notes a certain inconsistency in Myanmar's position on this subject, observing that Myanmar 'accepts with respect to the potential areas of overlap with India that even if [the

\footnotetext{
${ }^{61}$ Memorial Submitted by Bangladesh, in, Bangladesh v Myanmar, supra note 49, [4.23].

62 Reply of Bangladesh [4.30].

${ }^{63}$ Reply of Bangladesh [4.40].

64 Memorial Submitted by Bangladesh [4.35].

65 Reply of Bangladesh [4.17].
} 
Tribunal] cannot fix a tripoint between three States, it can indicate the "general direction for the final part of the maritime boundary between Myanmar and Bangladesh," and that doing so would be "in accordance with the well-established practise" of international courts and tribunals. ${ }^{, 66}$ Among Bangladesh's conclusions summarizing its position on the issue of third-party rights and the jurisdiction of the Tribunal are the following:

2. The delimitation by the Tribunal of a maritime boundary in the continental shelf beyond 200 [nautical miles] does not prejudice the rights of third parties. In the same way that international courts and tribunals have consistently exercised jurisdiction where the rights of third States are involved, ITLOS may exercise jurisdiction, even if the rights of the international community to the international seabed were involved, which in this case they are not.

3. With respect to the area of shelf where the claims of Bangladesh and Myanmar overlap with those of India, the Tribunal need only determine which of the two Parties in the present proceeding has the better claim, and effect a delimitation that is only binding on Bangladesh and Myanmar. Such a delimitation as between the two Parties to this proceeding would not be binding on India. ${ }^{67}$

In respect of the role of the CLCS, Bangladesh states:

[T]here is no conflict between the roles of ITLOS and the Commission in regard to the continental shelf. To the contrary, the roles are complementary. ITLOS has jurisdiction to delimit boundaries within the outer continental shelf; the Commission makes recommendations as to the delineation of the shelfs outer limits with the international seabed, provided there are no disputed claims between adjacent or opposite States. Indeed, the Commission may not make any recommendations on the outer limits until such dispute is resolved (by ITLOS or another judicial or arbitral body, or by agreement between the parties) - unless the parties give their consent that the Commission review their submissions. In the present case, the Commission is precluded from acting due to the Parties' disputed claims in the outer continental shelf and the refusal by at least one of them (Bangladesh) to consent to the Commission's actions. ${ }^{68}$

\section{Bangladesh contends:}

[I]f Myanmar's argument were accepted, ITLOS would have to wait for the CLCS to act and the CLCS would have to wait for ITLOS to act. The resulting catch-22 would mean that whenever parties are in dispute in regard to the continental shelf beyond 200 [nautical miles], the Compulsory

\footnotetext{
${ }^{66}$ Reply of Bangladesh [4.17].

${ }^{67}$ Reply of Bangladesh [4.91].

${ }^{68}$ Memorial Submitted by Bangladesh, [4.28 and 4.29].
} 
Procedures Entailing Binding Decisions under Part XV, Section 3 of UNCLOS would have no practical application. In effect, the very object and purpose of the UNCLOS dispute settlement procedures would be negated. Myanmar's position opens a jurisdictional black hole into which all disputes concerning maritime boundaries in the outer continental shelf would forever disappear. ${ }^{69}$

Summarizing its position, Bangladesh concludes in the Reply: 'In portraying CLCS recommendations as a prerequisite to exercise of jurisdiction by this Tribunal, Myanmar sets forth a circular argument that would make the exercise of ITLOS jurisdiction with respect to the continental shelf beyond 200 [nautical miles] impossible. This is not consistent with Part XV of the UNCLOS or with Article 78. ${ }^{, 70}$ It must be recalled that the jurisdiction of the Tribunal depends in all instances on the prior consent of the parties and that no sovereign State can be party to a case before an international court unless it has consented thereto. It is this consent to bring a dispute before the Tribunal that determines the Tribunal's jurisdiction over the dispute. However, the dispute and the applications [in French, demandes] should not be confused. Article 21 of the Statute of the Tribunal provides: 'The jurisdiction of the Tribunal comprises all disputes and all applications [demands] submitted to it in accordance with this Convention and all matters specifically provided for in any other agreement which confers jurisdiction on the Tribunal. ${ }^{71}$

This means that the Tribunal, in performing its judicial task, may choose the terms under which it will respond to the Parties' submissions. The Tribunal is therefore free to consider and decide the question of delimiting the continental shelf beyond 200 nautical miles separately. Myanmar's jurisdictional objection in respect of the delimitation of the continental shelf beyond 200 nautical miles is justified by the fact that Myanmar as Respondent accepted the jurisdiction of the Tribunal. Indeed, paragraph 12 of the minutes of

\footnotetext{
69 Reply of Bangladesh [4.7].

${ }^{70}$ Reply of Bangladesh [3.91 (1)].

71 The ICJ has defined a submission to be the 'precise and direct statement of a claim [demande] (Fisheries Judgment, [1951] ICJ Rep 116, 126). According to the Court, submissions may not be presented in interrogative form (Haya de la Torre, Judgment, [1951] ICJ Rep 71). And the Court considers that it has jurisdiction to interpret them, which allows it, where it deems necessary, to refrain from responding to them (Monetary Gold Removed from Rome in 1943, Preliminary [1954] ICJ Rep 19, 28). The Court wrote: The Italian Government contends that the Court has no jurisdiction to adjudicate upon these Submissions of the United Kingdom. The Court cannot consider itself as lacking jurisdiction to adjudicate upon the validity, withdrawal or cancellation of an application which has been submitted to it: to adjudicate upon such questions with a view to deciding upon the effect to be given to the Application falls within the purview of its judicial task.
} 
the consultations with the President of the Tribunal clearly states: 'During the course of the consultations, the delegation of Myanmar informed the President of the intention of Myanmar to file preliminary objections in case. In respect of this matter, a letter from the Agent of Myanmar dated 25 January 2010 was handed over the Registrar.' Those preliminary objections concern the delimitation of the continental shelf beyond 200 nautical miles between the two Parties.

The allocation of rights within the grey area is a very complex issue. In the Bangladesh $v$ Myanmar case, the delimitation line follows a geodetic line starting at an azimuth of $215^{\circ}$ until it reaches a point situated at 200 nautical miles from the baselines from which the breadth of the territorial sea of Bangladesh is measured.

In the case between Bangladesh and India, the delimitation line of the Arbitral Tribunal also creates a grey area beyond 200 nautical miles from the coasts of Bangladesh but within the 200 nautical miles of India. As Bangladesh does not have rights over the EEZ, the dividing line beyond 200 miles only delimits overlapping claims to the continental shelf. Consequently, Bangladesh has sovereign rights to explore the continental shelf and exploit 'mineral and other non-living resources of the seabed and subsoil together with living organisms belonging to sedentary species' east of the dividing line in the grey area. India, for its part, has sovereign rights over the EEZ regarding the superjacent waters.

The Arbitral Tribunal leaves it to the two States to determine the practical arrangements for the realization of their respective rights in the grey area. This judgment is singularly similar to that of the ITLOS in the case between Bangladesh and Myanmar.

Given the nature of the dividing line, Bangladesh alone exercises sovereign rights on the continental shelf of the two grey areas created by ITLOS and the Arbitral Tribunal (Annex VII). Therefore, neither India nor Myanmar can exploit the seabed and sub-soil in grey areas. ${ }^{72}$ These decisions of the two jurisdictions are debatable. The Indian judge, for instance, in the case between Bangladesh and India strongly objects to these decisions. He explains: 'Sovereign rights of a coastal State over the water column and the seabed and its subsoil are considered as two indispensable and inseparable parts of the coastal State's rights in the

\footnotetext{
72 Bangladesh v India, supra note 49, [505]; Bangladesh $v$ Myanmar, supra note 49 [474] where ITLOS decided that '.. in the area beyond Bangladesh's exclusive economic zone that is within the limits of Myanmar's exclusive economic zone, the maritime boundary delimits the Parties' rights with respect to the seabed and subsoil of the continental shelf but does not otherwise limit Myanmar's rights with respect to the exclusive economic zone, notably those with respect to the superjacent waters.'
} 
EEZ; ${ }^{73}$ Anticipating the difficulties likely to arise in the management and sharing of maritime species, Dr. Rao indicates: 'As a matter of policy, international courts and tribunals should avoid delimiting boundaries in a way that leaves room for potential conflicts between the parties ... The grey area also has the potential to exacerbate bilateral relations and pose avoidable security problem. ${ }^{74}$ In dealing with the case, D. A. Anderson observed rightly: ${ }^{75}$

In light of the Bangladesh/Myanmar case, as well as the North Sea Continental Shelf case, the decision to depart from the provisional equidistance line to take account of the concavity of the relevant coasts was supported by precedent and thus predictable. But the (majority) decision suffers from a lack of transparency concerning the construction of the delimitation line.

The Tribunal's decision to extend the delimitation of the continental shelf beyond 200 nautical miles followed that of ITLOS in the same Bay of Bengal. The legislative history of the Third United Nations Conference on the Law of the Sea shows that the Bay of Bengal is a special case, a factor that was not, however, brought out in terms of the award. In delimitation cases concerning other parts of the world, different considerations may apply. The existence of two grey areas in the Bay of Bengal may complicate relations over fisheries issues in the future. In some boundary negotiations, the parties have agreed upon a "joint area" for a particular purpose and at the same time have defined the applicable regime for its management. The two grey areas appear at present to lack such measures of agreement and cooperation.

\subsection{Jurisprudence in the delimitation of the continental shelf beyond 200 nautical miles between the parties: should a precedent have been created?}

Delimitation is determined by agreement or by adjudication by a court or tribunal. The outer limits of the continental shelf are established by the coastal State on the basis of recommendations by the Commission and are "final and binding". The recommendations of the Commission are submitted in writing to the coastal State which made the submission and to the Secretary-General of the United Nations. ${ }^{76}$ For this reason,

\footnotetext{
73 Ibid Dissenting opinion of Dr. Rao [31].

74 Ibid [35-37].

75 DA Anderson, Bay of Bengal Maritime Boundary (Bangladesh v India), 109 Am J Intl L (2015) $146-154,153$

76 Annex II, article 6, [3] of the Convention.
} 
article 7 of Annex II provides: 'Coastal States shall establish the outer limits of the continental shelf in conformity with the provisions of article 76 , paragraph 8 , and in accordance with the appropriate national procedures.' The thrust of these rules is to establish by implication that any delimitation of the continental shelf, or any delineation of its outer limits beyond 200 nautical miles, effected unilaterally by one State regardless of the views of the other State or States concerned, or established otherwise than under article 76 , paragraph 8 , is in international law not opposable to those States. ${ }^{77}$

'The delimitation of sea areas has always an international aspect; it cannot be dependent merely upon the will of the coastal State as expressed in its municipal law. Although it is true that the act of delimitation is necessarily a unilateral act, because only the coastal State is competent to undertake it, the validity of the delimitation with regard to other States depends upon international law. ${ }^{, 78}$

Under the circumstances of the case, can the Tribunal delimit the continental shelf beyond 200 nautical miles between Bangladesh and Myanmar? Specifically, can it do so even before the Parties' claims to the continental shelf have been confirmed on the basis of the recommendations by the CLCS referred to in article76, paragraph 8 ? Each Party disputes the other's entitlement to continental shelf area beyond 200 nautical miles. The circumstances:

\section{(a) Treaty obligations (article 76 and Annex II of the Convention).}

Paragraph 1 of article 76 of the Convention defines the continental shelf and establishes two criteria. The first is the distance criterion for those States whose continental margin does not extend more than 200 nautical miles from the baselines. In this case, the outer limit of the juridical continental shelf merges with the outer limit of the EEZ. The second criterion is a geomorphological one for those States whose continental margin extends more than 200 miles from the baselines. In this case, the coastal State must show the CLCS that the natural prolongation of its land mass extends more than 200 nautical miles. For purposes of this determination, there apply (i) two formulae determining the outer edge of the continental margin and (ii) constraints limiting the expansion of States. The outer limit of the juridical continental shelf can be established by the

\footnotetext{
77 Delimitation of the Maritime Boundary in the Gulf of Maine Area, supra note 13, 246, 292 [87].

78 Fisheries case (UK v Norway) [1951] ICJ Rep 116, 132.
} 
combined application, in accordance with precise rules, of the lines resulting from the formulae and constraints. Scientific data must be gathered at sea to produce the information needed to apply the formulae. The coastal State establishes the outer limits of the continental shelf on the basis of the recommendations made by the CLCS (article 76, para. 8, of the Convention and Annex II of the Convention). The Secretary-General of the United Nations gives due publicity to these limits. Article 3, paragraph 1, of Annex II to the Convention describes the Commission's functions as follows:

1. The functions of the Commission shall be:

(a) to consider the data and other material submitted by coastal States concerning the outer limits of the continental shelf in areas where those limits extend beyond 200 nautical miles, and to make recommendations in accordance with article 76 and the Statement of Understanding adopted on 29 August 1980 by the Third United Nations Conference on the Law of the Sea;

(b) to provide scientific and technical advice, if requested by the coastal State concerned during the preparation of the data referred to in subparagraph (a).

This means that the authority to examine lies with the Commission if the information furnished to it proves that the conditions laid down in article 76 for purposes of establishing the outer limits of the continental shelf are satisfied by the coastal State. Under the terms of the Convention, the power to assess the scientific and technical data submitted by the coastal State is vested exclusively in the Commission.

The Tribunal complicated its task by delimiting the continental shelf beyond 200 nautical miles even though the Commission has not pronounced upon the outer limits of each Party's continental shelf.

\section{(b) Suspension of a submission by the CLCS}

'In cases where a land or maritime dispute exists, the Commission shall not consider and qualify a submission made by any of the States concerned in the dispute. However, the Commission may consider one or more submissions in the areas under dispute with prior consent given by all States that are parties to such a dispute' (Annex I, para. 5(a), of the Rules of Procedure of the Commission).

In accordance with this, the Commission stated on the subject of the submission made by Myanmar pursuant to article 76 on 16 December 2008: 
noting that there had been no developments to indicate that consent existed on the part of all States concerned allowing the consideration of the submission notwithstanding the existence of a dispute in the region, the Commission decided to further defer the establishment of a subcommission for the consideration of the submission made by Myanmar. It was also decided that, since the submission remained next in line for consideration as queued in the order in which it was received, the Commission would revisit the situation at the time of establishment of its next subcommission.

The Commission reiterated this decision at its twenty-seventh session ( 7 March-21 April 2011). Considering the positions of the Parties as described above, the Tribunal will first address the main point in dispute, namely whether or not they have any entitlement to the continental shelf beyond 200 nautical miles. In this regard, the Tribunal will first examine the Parties' positions in regard to their respective entitlements; it will analyse the meaning of "natural prolongation" and its interrelation with that of continental margin. The Tribunal will then ascertain whether it has jurisdiction in the present case to determine the entitlements of the Parties to the continental shelf beyond 200 nautical miles. Finally, the Tribunal will determine whether there is overlap between any entitlements the Parties may have to the continental shelf beyond 200 nautical miles. On the basis of these determinations, the Tribunal will take a decision on the delimitation of the continental shelf of the Parties beyond 200 nautical miles. ${ }^{79}$

While both Parties make claims to the continental shelf beyond 200 nautical miles, each disputes the other's claim. Thus, according to them, there are no overlapping claims over the continental shelf beyond 200 nautical miles. It follows either that the question of delimitation does not arise or that the delimitation between the Parties must be effected so as to leave the entire continental shelf area beyond 200 nautical miles to one Party alone.

Bangladesh submits that pursuant to article 76 of the UNCLOS, it has an entitlement to the continental shelf beyond 200 nautical miles. It further submits that Myanmar enjoys no such entitlement because its land territory has no natural prolongation into the Bay of Bengal beyond 200 nautical miles. Therefore, according to Bangladesh, there is no overlapping continental shelf beyond 200 nautical miles between the Parties, and it alone is entitled to the continental shelf claimed by both of them. Bangladesh thus submits that any boundary in this area must

\footnotetext{
79 Bangladesh v Myanmar, supra note 49, 96 [401].
} 
lie no further seaward from Myanmar's coast than the 200 nautical mile "juridical shelf" provided for in article $76 .{ }^{80}$

In respect of its own entitlement to the continental shelf beyond 200 nautical miles, Bangladesh asserts that 'the outer continental shelf claimed by Bangladesh is the natural prolongation of Bangladesh's land territory by virtue of the uninterrupted seabed geology and geomorphology, including specifically the extensive sedimentary rock deposited by the Ganges-Brahmaputra river system. ${ }^{, 81}$ To prove this, Bangladesh provided the Tribunal with scientific evidence to show that there is a geological and geomorphological continuity between the Bangladesh land mass and the Bay of Bengal. In addition, Bangladesh submits that its entitlement to the outer continental shelf, the limits of which have been established by the so-called Gardiner formula based on sediment thickness, extends well beyond 200 nautical miles.

In respect of Myanmar's entitlement, Bangladesh claims that Myanmar is not entitled to a continental shelf beyond 200 nautical miles because it cannot meet the physical test of natural prolongation in article 76 , paragraph 1 , which requires evidence of a geological character connecting the seabed and subsoil directly to the land territory. According to Bangladesh, there is overwhelming and unchallenged evidence of a "fundamental discontinuity" between the landmass of Myanmar and the seabed beyond 200 nautical miles (RB, para. 4.62). Bangladesh contends that the tectonic plate boundary between the Indian and Burma Plates is manifestly 'a marked disruption or discontinuance of the seabed' that serves as 'an indisputable indication of the limits of two separate continental shelves, or two separate natural prolongations. $^{\text {, }}{ }^{2}$

In its note verbale of 23 July 2009 to the Secretary-General of the United Nations, Bangladesh stated that the areas claimed by Myanmar in its submission to the Commission as part of its putative continental shelf were in fact the natural prolongation of Bangladesh and hence Myanmar's claim was disputed by Bangladesh (MB, vol. III, Annex 21). In its submission of 25 February 2011 to the Commission, Bangladesh reiterated this position, stating that it 'disputes the claim by Myanmar to areas of outer continental shelf because those claimed areas 'form part

\footnotetext{
${ }^{80} \mathrm{MB}[7.37]$

${ }^{81} \mathrm{MB}[7.43]$

${ }^{82} \mathrm{RB}[4.62]$.
} 
of the natural prolongation of Bangladesh. ${ }^{83}$ In summing up, Bangladesh states in its Memorial:

That by reason of the significant geological discontinuity which divides the Burma plate from the Indian plate, Myanmar is not entitled to a continental shelf in any of the areas beyond 200 [nautical miles]. That Bangladesh is entitled to claim sovereign rights over all of the bilateral shelf area beyond 200 [nautical miles] claimed by Bangladesh and Myanmar ...; That, vis-à-vis Myanmar only, Bangladesh is entitled to claim sovereign rights over the trilateral shelf area claimed by Bangladesh, Myanmar and India ... (MB, paragraph 7.43).

Myanmar rejects Bangladesh's contention that Myanmar has no entitlement to a continental shelf beyond 200 nautical miles. While Myanmar does not contradict Bangladesh's evidence from a scientific point of view, it emphasizes that the existence of a geological discontinuity in front of the coast of Myanmar is simply irrelevant to the case. According to Myanmar, the entitlement of a coastal State to a continental shelf beyond 200 nautical miles is not dependent on any "test of natural geological prolongation". What determines such entitlement is the physical extent of the continental margin, that is to say its outer edge, to be identified in accordance with article 76, paragraph 4 , of the Convention. ${ }^{84}$

Myanmar asserts that it identified the outer edge of its continental margin by reference to the Gardiner formula, which is embodied in article 76, paragraph 4(a)(i). The Gardiner line thus identified is well beyond 200 nautical miles, and, consequently, so is the outer edge of Myanmar's continental margin. Therefore, Myanmar is entitled to a continental shelf beyond 200 nautical miles in the present case. It has accordingly submitted the particulars of the outer limits of its continental shelf to the Commission pursuant to article 76, paragraph 8 , of the Convention. ${ }^{85}$

In a note verbale dated 31 March 2011 to the Secretary-General of the United Nations, Myanmar stated: 'Bangladesh has no continental shelf extending beyond 200 [nautical miles] measured from base lines established in accordance with the international law of the sea' and 'Bangladesh's right over a continental shelf does not extend either to the

\footnotetext{
${ }^{83}$ Executive Summary, appearing in RB, vol. III, Annex R3 [5.9].

${ }^{84}$ ITLOS/PV.11/11, 20, line 28.

${ }^{85}$ CMM [A.2].
} 
limit of 200 [nautical miles] measured from lawfully established base lines, or, a fortiori, beyond this limit. ${ }^{86}$

Myanmar argues that Bangladesh has no continental shelf beyond 200 nautical miles because the delimitation of the continental shelf between Bangladesh and Myanmar stops well before reaching the 200-nauticalmile limit measured from the baselines of both States (CMM, para. 5.160). In these circumstances, the question of the delimitation of the continental shelf beyond this limit is moot and does not need to be considered further by the Tribunal. ${ }^{87}$

Determining the entitlements of the two States to the continental shelf beyond 200 nautical miles and their respective extent is a prerequisite for any delimitation.

This consists of 'draw[ing] the exact line or lines where the extension in space of the sovereign powers and rights of [one State concerned] meets those of [the other]. ${ }^{88}$ The intimate link between States' entitlement to a maritime area and the delimitation of a maritime area between neighbouring States is "self-evident". ${ }^{89}$ It is apparent that "le titre commande la délimitation, la délimitation est fille du titre' ('entitlement determines delimitation, delimitation issues from entitlement' [translation by the Registry]). ${ }^{90}$

On the subject of determining the Parties' entitlements, the Tribunal explains $^{91}$ that not every coast generates entitlement to a continental shelf extending beyond nautical miles. The Commission in some instances has based its recommendations on its view that an entire area or part of an area included in a coastal State's submission comprises part of the deep ocean floor. Myanmar does not deny that the continental shelf of Bangladesh, if not affected by the delimitation within 200 nautical miles, would extend beyond that distance. Bangladesh does not deny that there is a continental margin off Myanmar's coast but argues from its interpretation of article 76 of the Convention that this margin has no natural prolongation beyond 50 nautical miles off that coast. The Tribunal says that the problem lies in the Parties' disagreement as to what constitutes the continental margin (para. 442 of the Judgment). It

\footnotetext{
${ }^{86}$ RM, Appendix, 198.

87 CMM 165.

88 Aegean Sea Continental Shelf [1978] ICJ Rep 3, 35 [85].

89 Continental Shelf (Libyan Arab Jamahiriya v Malta), supra note 13, 13, 30 [27].

90 P Weil, Vers une conception territorialiste de la délimitation maritime, in, Mélanges Michel Virally (ed) Le droit international au service de la paix de la justice et du développemen (Paris, Pedone 1991), 501-511, 511.

91 Bangladesh v Myanmar, supra note 49, [200].
} 
notes that the Bay of Bengal presents a unique situation and that its sea floor is covered by a thick layer of sediments 14 to 22 kilometres deep. The Tribunal states that, given the presence of these sedimentary rocks, both Parties included in their submissions to the Commission data indicating that their entitlement to the continental margin extending beyond 200 nautical miles was based to a great extent on article 76, paragraph $4(\mathrm{a})(\mathrm{i})$, of the Convention. ${ }^{92}$

The entitlement to be ascertained cannot but be tied to the definition itself of the continental shelf. An exercise in maritime delimitation consists of applying the natural sciences to ascertain the extent of the natural prolongation under the sea of each of the two States and of making a finding on-not awarding - the extent of the submarine basement nature has placed before each of the two States.

In past decades, it was the concept of natural prolongation of a State's land territory that made it possible to determine how far seaward the State's rights to the seabed extended. Today, it is the criterion of distance that performs this function for the continental shelf, the EEZ and the territorial sea. Let us recall that every coastal State has the right to a continental shelf, which is the natural prolongation of its territory. This right can be limited in five different ways: (1) to 200 nautical miles where the outer edge of the continental margin lies within that distance; (2) by the outer edge of the continental margin; (3) to a distance of 350 nautical miles where the outer edge of the continental margin lies at a greater distance than that; (4) by the rights and entitlements of third States; and (5) by the rights and entitlements of the international community represented by the International Seabed Authority (ISA). It would have been good to have specific data on the continental shelf of Bangladesh and Myanmar beyond 200 nautical miles. The distance criterion is linked to the law relating to a State's legal entitlement to the continental shelf. As the ICJ has said, ${ }^{93}$ the law applicable to the dispute, i.e., to claims relating to continental shelves located less than 200 miles from the coasts of the States in question, is based not on geological or geomorphological criteria, but on a criterion of distance from the coast or, to use the traditional term, on the principle of adjacency as measured by distance.

The problem here lies in the fact that this criterion does not apply to the continental shelf beyond 200 miles. The consequences of the development of continental shelf law can be seen with regard to both

\footnotetext{
92 Ibid [445].

93 Libyan Arab Jamahiriya v Malta, supra note 13, 13, 46 [61].
} 
verification of entitlement and delimitation as between rival claims. On the basis of the law now applicable, namely the distance criterion, has it been proved that Bangladesh and Myanmar hold valid entitlements to the seabed areas they claim? What is the impact of considerations of distance on the delimiting itself, which must both fix limits on the States' maritime projections seaward and delimit these various areas between the two States? It has to be kept in mind in making this assessment that the delimitation must achieve an equitable result by applying equitable principles to the relevant circumstances. The adjudicator must decide "on the basis of law". ${ }^{94}$

To this end, the International Court of Justice has established the status of equitable principles. It explains that the judicial decisions are at one in holding that the delimitation of a continental shelf boundary must be effected by the application of equitable principles in all the relevant circumstances in order to achieve an equitable result. This approach is not entirely satisfactory because it employs the term equitable to characterize both the result to be achieved and the means to be applied to reach this result. ${ }^{95}$ It is, however, the goal - the equitable result-and not the means used to achieve it, which must be the primary element in this duality of characterization. 'Equity as a legal concept is a direct emanation of the idea of justice. The Court whose task is by definition to administer justice is bound to apply it. ${ }^{96}$ A distinction must however be made between applying equitable principles and giving a decision ex aequo et bono, because 'it is not a question of applying equity simply as a matter of abstract justice, but of applying a rule of law which itself requires the application of equitable principles, in accordance with the ideas which have always underlain the development of the legal régime of the continental shelf in this field. ${ }^{97}$

Thus the justice of which equity is an emanation is not abstract justice but justice according to the rule of law, which is to say that its application should display consistency and a degree of predictability. Even though it looks with particularity to the peculiar circumstances of an instant case, it also looks beyond it to principles of more general application. ${ }^{98}$ Equitable principles therefore take on a normative character.

\footnotetext{
94 Delimitation of the Maritime Boundary in the Gulf of Maine Area, supra note 13, 246, 278 [59].

95 Tunisia v Libyan Arab Jamahiriya, supra note 9, 18, 59 [70].

96 Ibid 60 [71].

97 North Sea Continental Shelf, supra note 2, 3, 47 [85].

98 Libyan Arab Jamahiriya v Malta, supra note 13, 13, 39 [45] and B Kunoy, The Delimitation of an Indicative Area of Overlapping Entitlement to the Outer Continental Shelf, British Yrbk Intl L (2012) 61-81, $63,81$.
} 
The present Judgment is that it does not succeed in determining Bangladesh's and Myanmar's precise entitlements to the continental shelf beyond 200 nautical miles. Nor does it succeed in establishing the extent of those entitlements. On the issue of its jurisdiction to decide the Parties' entitlements, the Tribunal points out the need to make a distinction between the notion of entitlement to the continental shelf beyond 200 nautical miles and that of the outer limits of the continental shelf. It notes that 'article 83 of the Convention addresses the delimitation of the continental shelf between States with opposite or adjacent coasts without any limitation as to area. It contains no reference to the limits set forth in article 76 , paragraph 1 , of the Convention. Article 83 applies equally to the delimitation of the continental shelf both within and beyond $200 \mathrm{~nm}$.' The Tribunal explains that a coastal State's entitlement to the continental shelf exists by the sole fact that the basis for it is present; it does not require the establishment of outer limits. Article 77 of the Convention is cited in this connection. ${ }^{99}$

This illustrates a fundamental difference to be observed between land delimitation - which upholds vestiges of the colonial era-and maritime delimitation. Unlike the former, the latter does not involve identifying the better title, hence the legally dispositive one; it involves resolving the difficulties created by the coexistence of two entitlements of equal legal value. 'While suum cuique tribuere is the objective in land delimitation, maritime delimitation is destined to cut back the entitlement of each. One involves recognition, enshrinement; the other reduction, sacrifice, cutting back. This explains the difference in the role played by effectivity in land and maritime delimitations. Occupation, effective exercise of State sovereignty, acts of sovereignty: all elements which help to establish the better, hence legally prevailing, title in land delimitation cases but which have no relevance in maritime delimitation. ${ }^{100}$

Unable to determine the Parties' exact entitlements to the continental shelf beyond 200 nautical miles, or to establish their extent so as to ascertain whether those entitlements are concurrent, overlapping or intertwined, the Tribunal takes another tack. It states:

The scientific data and analyses presented in this case, which have not been contested, do not establish that Myanmar's continental shelf is limited to $200 \mathrm{~nm}$

\footnotetext{
99 Bangladesh v Myanmar, supra note 49, [361].

${ }^{100} \mathrm{P}$ Weil, Délimitation maritime et délimitation terrestre, International Law at a Time of Perplexity: Essays in Honour of Shabtai Rosenne (Dordrecht, Martinus Nijhoff Publishers, 1989), 1021-1026, 1024.
} 
under article 76 of the Convention, and instead indicate the opposite"101; [and] [t]he Tribunal accordingly concludes that both Bangladesh and Myanmar have entitlements to a continental shelf extending beyond $200 \mathrm{~nm}$. The submissions of Bangladesh and Myanmar to the Commission clearly indicate that their entitlements overlap in the area in dispute in this case. ${ }^{102}$

In respect of the Area, the Tribunal adds its observation that, as is evident from the Parties' submissions to the Commission, the continental shelf beyond 200 nautical miles that is the subject of delimitation here is situated far from the Area (para. 368 of the Judgment). It is indeed true that the Commission has neither confirmed nor invalidated the scientific information in the submissions made to it, since it has suspended its consideration of them on account of the dispute that is the object of the present case (on the subject of the decision to defer consideration of the respective submissions of Myanmar and Bangladesh). ${ }^{103}$ The Parties dispute each other's claims to the continental shelf. While each makes a claim to continental shelf area beyond 200 nautical miles, each challenges the other's claim. Accordingly, there are no overlapping claims to the continental shelf beyond 200 nautical miles. Instead, each claim is exclusive of the other. From the Parties' point of view, the question of delimitation does not arise and it may be that the delimitation should be effected so as to leave the entire continental shelf area beyond 200 miles to one Party or the other. As a result, we are reduced to conjecture. And, by drawing the line it envisages, is the Tribunal not prejudicing the rights of the international community? Beyond doubt, the right process was to have recourse first to the Commission.

It must be kept in mind that judges find entitlements; under no circumstances may they grant them. Owing to the nature of the judicial function and the nature of entitlements, it is all the more imperative that courts rely on existing law, however uncertain may be the principles or rules deriving from the requirement of an equitable solution. The Tribunal pretends to base its decision on principles of law, but, for lack of sufficiently precise substantive rules founded on general international law, it is reduced to ruling by the exercise of discretion.

\footnotetext{
101 Bangladesh v Myanmar, supra note 49, [448].

102 Ibid [449].

${ }^{103}$ See the Statement by the Chairman of the Commission on the Limits of the Continental Shelf on the Progress of Work in the Commission, CLCS/64, 1 October 2009, 10 [40], and the Statement by the Chairman of the Commission on the Limits of the Continental Shelf on the Progress of Work in the Commission, CLCS/72, (16 September 2011), 7 [22].
} 
This approach rebounds on the Tribunal's chosen method of delimitation-equidistance/relevant circumstances-insofar as the elements of the delimitation exercise become inoperative, that is to say inapplicable, for three reasons:

First, it is by juxtaposing titles which are concurrent, overlapping or intertwined throughout their full extent that an idea of the relevant area can be derived, and this in turn makes it possible to ensure that there is no disproportion. This process plays an important role in the delimitation operation by assessing the relationship between the length of the coasts of the States concerned and the extent of maritime area accruing to them. This means that it is difficult to produce from rough guesses the explicit result expected of delimitation, which must achieve an equitable result. Indeed, it has by now become unclear whether this is a dispute concerning attribution of one territory or a dispute concerning delimitation of two territories, since the relevant area is nonexistent because indeterminate.

'In the view of the Tribunal, the delimitation method to be employed in the present case for the continental shelf beyond 200 nautical miles should not differ from that within $200 \mathrm{~nm}$. Accordingly, the equidistance/relevant circumstances method continues to apply for the delimitation of the continental shelf beyond $200 \mathrm{~nm}$. This method is rooted in the recognition that sovereignty over the land territory is the basis for the sovereign rights and jurisdiction of the coastal State with respect to both the exclusive economic zone and the continental shelf. This should be distinguished from the question of the object and extent of those rights, be it the nature of the areas to which those rights apply or the maximum seaward limits specified in articles 57 and 76 of the Convention. The Tribunal notes in this respect that this method can, and does in this case, permit resolution also beyond $200 \mathrm{~nm}$ of the problem of the cut-off effect that can be created by an equidistance line where the coast of one party is markedly concave., ${ }^{104}$

This method involves three well-defined stages. The first consists of plotting the provisional equidistance line. At this stage, the judge pays no heed to any relevant circumstances and the line is drawn in accordance with strictly geometric criteria on the basis of objective data. The course of the final line must produce an equitable solution (articles 74 and 83 of the Convention). This is why in the second stage the judge considers whether there are any factors calling for an adjustment or

104 Bangladesh v Myanmar, supra note 49, [449]. 
displacement of the provisional equidistance line to achieve an equitable result. Finally, in the third stage the judge must verify that the line does not lead to an inequitable result by reason of any marked disproportion between the ratio of the respective coastal lengths and the ratio between the relevant maritime areas of the two States by reference to the delimitation line.

Next, under these conditions identifying the relevant circumstances becomes a tricky exercise characterized by uncertainty in respect of the continental shelf beyond 200 nautical miles. The role of proportionality, the conduct of the Parties, socio-economic elements, the general geographical setting, and the geology and geomorphology could furnish factual information for the adjudicator to take into consideration in drawing an equitable line. The approach changed somewhat and an attempt was made to re-establish order by assessing the weight to be accorded to relevant circumstances in any particular delimitation. According to the ICJ: 'In fact, there is no legal limit to the considerations which States may take account of for the purpose of making sure that they apply equitable procedures, and more often than not it is the balancing-up of all such considerations that will produce this result rather than reliance on one to the exclusion of all others.

The problem of the relative weight to be accorded to different considerations naturally varies with the circumstances of the case. ${ }^{, 105}$ But it is not so where a judicial or arbitral body applies equitable procedures. For such a body, although there is assuredly no exhaustive list of considerations, it is evident that only 'those that are pertinent to the institution of the continental shelf as it has developed within the law, and to the application of equitable principles to its delimitation, will qualify for inclusion. Otherwise, the legal concept of continental shelf could itself be fundamentally changed by the introduction of considerations strange to its nature. ${ }^{106}$ In the case at hand can a convincing link be established between the relevant circumstances cited by just one Party and the adversarial continental shelf claims asserted by Bangladesh and Myanmar?

Specifically, does the equidistance line duly take account of the relevant circumstances, i.e., the cut-off effect it produces, the concavity of the Bangladesh coast and the Bengal depositional system? Do these

\footnotetext{
105 North Sea Continental Shelf, supra note 2, 3, 50 [93].

106 Continental Shelf (Libyan Arab Jamahiriya/Malta), supra note 13, 13, 40 [48].
} 
factors call for an adjustment or shifting of the equidistance line beyond 200 nautical miles in order to arrive at an equitable result? Did the Tribunal ensure that the decided delimitation line did not lead to an inequitable result by reason of a marked disproportion between the ratio of the respective coastal lengths and the ratio of the relevant maritime areas? What are the relevant maritime areas attributed by the delimitation line to Bangladesh and Myanmar beyond 200 nautical miles?

Bangladesh contends that the relevant circumstances in the delimitation of the continental shelf beyond 200 nautical miles include the geology and geomorphology of the seabed and subsoil, because entitlement beyond 200 nautical miles depends entirely on natural prolongation while within 200 nautical miles it is based on distance from the coast. ${ }^{107}$ According to Bangladesh, its entitlement to the continental shelf beyond 200 nautical miles "rests firmly" on the geological and geomorphological continuity between its land territory and the entire seabed of the Bay of Bengal. Bangladesh states that Myanmar 'at best enjoys only geomorphological continuity between its own landmass and the outer continental shelf. ${ }^{108}$ In Bangladesh's view, therefore, 'an equitable delimitation consistent with article 83 must necessarily take full account of the fact that Bangladesh has the most natural prolongation into the Bay of Bengal, and that Myanmar has little or no natural prolongation beyond 200' nautical miles. ${ }^{109}$

Another relevant circumstance cited by Bangladesh is 'the continuing effect of Bangladesh's concave coast and the cut-off effect generated by Myanmar's equidistance line, or by any other version of an equidistance line.' According to Bangladesh, '[t]he farther an equidistance or even a modified equidistance line extends from a concave coast, the more it cuts across that coast, continually narrowing the wedge of sea in front of it. ${ }^{110}$

Given its position that Bangladesh's continental shelf does not extend beyond 200 nautical miles, Myanmar did not present arguments regarding the existence of relevant circumstances relating to the delimitation of the continental shelf beyond 200 nautical miles. In this connection the Tribunal observes that Myanmar stated that there are no

\footnotetext{
107 ITLOS/PV.11/6, 24, line 34.

108 ITLOS/PV.11/6, 26, lines 2-3.

109 ITLOS/PV.11/6, 26, lines 16-19.

110 ITLOS/PV.11/6, 26, lines 35-37.
} 
relevant circumstances requiring a deflection of the provisional equidistance line in the context of the delimitation of the continental shelf within 200 nautical miles.

Finally, a question may be raised on the nature of the line dividing the continental shelf beyond 200 nautical miles. The Tribunal has decided that the maritime boundary more than 200 nautical miles from Bangladesh continues along the geodetic line starting from point 11 at an azimuth of $215^{\circ}$ as identified in operative paragraph 5, until it reaches the area where the rights of third States may be affected. ${ }^{111}$ The Tribunal has decided that, in view of the geographic circumstances in the present case (concavity and cut-off effect, St Martin's Island), the delimitation line must be deflected at the point where it begins to cut off the seaward projection of the Bangladesh coast and that the direction of the adjustment is to be determined in the light of this circumstance. In this regard, we must confess to great surprise at paragraphs 235,236 and 237 of the Judgment, since the Tribunal has opted to follow the equidistance/relevant circumstances method. It is only when the equidistance method leads to an inequitable and unreasonable result that recourse to other methods is justified. Thus, it is an inherent contradiction, a logical paradox, to change approach.

If this delimitation operation is justifiable for the continental shelf within 200 nautical miles and the exclusive economic zone, it is wholly inappropriate for the continental shelf beyond 200 nautical miles because the Parties' entitlements remain undefined: unless there are overlapping, equal entitlements to a given area, there is hardly any call for maritime delimitation. Good sense required terminating the delimitation line at the 200-nautical-mile limit, not beyond.

Under the circumstances of the present case, the Tribunal should have sought a preliminary ruling in order to settle this last part of the dispute. It should have made an Order of referral to that end. There has been no recourse to the referral-for-preliminary-ruling mechanism in international law. It is a concept of European Union law applicable in the courts of the European Union Member States.

The preliminary-ruling procedure affords national courts the possibility of seeking the views of the Court of Justice of the European Union on the interpretation or validity of Community law in the context of litigation before them. The procedure aims at ensuring legal certainty through the uniform application of Community law throughout the

\footnotetext{
111 Paragraph of the operative part of the Judgment, Bangladesh v Myanmar, supra note 49.
} 
European Union. The procedure is now provided for in articles 256 and 267 of the Treaty on the Functioning of the European Union (TFEU).

The Tribunal alone can do this. It is necessary to recall here the different views expressed by international courts and tribunals on the subject of delimitation beyond 200 nautical miles. In the Arbitration between Barbados and the Republic of Trinidad and Tobago, relating to the delimitation of the exclusive economic zone and the continental shelf between them, the Arbitral Tribunal said 'As will become apparent, however, the single maritime boundary which the Tribunal has determined is such that, as between Barbados and Trinidad and Tobago, there is no single maritime boundary beyond $200 \mathrm{~nm}$. The problems posed by the relationship in that maritime area of CS and EEZ rights are accordingly problems with which the Tribunal has no need to deal. The Tribunal therefore takes no position on the substance of the problem posed by the argument advanced by Trinidad and Tobago. ${ }^{, 12}$ In the case concerning Territorial and Maritime Dispute between Nicaragua and Honduras in the Caribbean Sea, the ICJ said:

The Court may accordingly, without specifying a precise endpoint, delimit the maritime boundary and state that it extends beyond the $82^{\text {nd }}$ meridian without affecting third-State rights. It should also be noted in this regard that in no case may the line be interpreted as extending more than 200 nautical miles from the baselines from which the breadth of the territorial sea is measured; any claim of continental shelf rights beyond 200 miles must be in accordance with Article 76 of UNCLOS and reviewed by the Commission on the Limits of the Continental Shelf established thereunder. ${ }^{113}$

Further, the arbitral award in the case concerning Delimitation of Maritime Areas between Canada and France (St Pierre and Miquelon) reads: 'It is not possible for a tribunal to reach a decision by assuming hypothetically the eventuality that such rights will in fact exist'. ${ }^{114}$ International courts and tribunals in these various cases have endeavoured to apply positive law without seeking to create precedent.

The ITLOS, the CLCS, the ISA and the Meeting of States Parties to the Convention are organs set up by the Convention, and each must assume a given role assigned to it under the Convention, that of guardian and authoritative interpreter being for the Tribunal. This creates a limitation - an important one for the Tribunal-on the

\footnotetext{
112 XXVII RIAA 147, 242 [368] (Decision of 11 April 2006).

113 Supra note 13, 659, 759 [319].

114 Decision of 10 June 1992, 31 ILM (1992) 1145, 1172 [81] (English translation); see also XXI RIAA 265, $293[81]$ (French version).
} 
exercise of its jurisdiction, for not only does the Convention specifically assign to the Commission the task of:

consider[ing] the data and other material submitted by coastal States concerning the outer limits of the continental shelf in areas where those limits extend beyond 200 nautical miles, and ... mak[ing] recommendations in accordance with article 76 and the Statement of Understanding adopted on 29 August 1980 by the Third United Nations Conference on the Law of the Sea.

In this regard, the Commission enjoys the exclusive, discretionary authority to carry out the tasks entrusted to it and the Tribunal must take account of this in the exercise of its jurisdiction in the present case.

For this reason, the Tribunal should have referred the matter to the Commission at this stage in the proceedings, without there being any need for one of the Parties to request it to do so, since the Tribunal should have considered itself unable to dispense justice in the circumstances of the case. It is for the Tribunal to judge whether to make the referral.

If the dispute could be settled solely on the basis of international law, if the question were substantively identical to one already resolved by the international jurisprudence, or if applying the delimitation rules and principles could lead to an equitable result and be in accordance with article 76 of the Convention, a referral would have been pointless. However, in the three cases in which the question has arisen-St Pierre and Miquelon arbitration, Arbitration between Barbados and the Republic of Trinidad and Tobago, ${ }^{115}$ and Territorial and Maritime Dispute between Nicaragua and Honduras in the Caribbean Sea ${ }^{116}$ - the judicial and arbitral bodies exercised caution and confined themselves to recalling the law in force.

There was a real need to request a preliminary ruling by the Commission so that the validity of the entitlements claimed by the Parties to the dispute before the Tribunal could be assessed. This would have enabled us to dispense justice to Bangladesh and Myanmar and to settle this dispute once and for all. This would also have paved the way for other international fora (the ICJ and arbitral tribunals) to deal with this difficult issue: this was the judicious course.

\footnotetext{
115 Delimitation of Maritime Areas between Canada and France (St Pierre \& Miquelon) [1992] XXI RIAA [78 \& 7] (in French); 31 ILM (1992) [78 \& 79] (in English). Barbados v Republic of Trinidad and Tobago [2006] XXVII RIAA [213].

116 Case concerning the Arbitral Award made by the King of Spain on 23 December 1906 (Nicaragua v Honduras) [1960] ICJ Rep 192 [319].
} 
For this purpose, the Tribunal should have immediately notified the President of the Meeting of States Parties and the Chairman of the Commission with a view to lifting the suspension, dating from 11 May 2011, of consideration of Myanmar's submission. It should be kept in mind that Myanmar is first in the queue and the examination of its submission would have sufficed for the Tribunal in the exercise of its jurisdiction because the data and information furnished by Bangladesh are uncontested.

The Tribunal should have empowered the President and the two judges ad hoc to act so as to ensure equality of the Parties in the process. A memorandum of understanding with the Commission and a specific timetable could then have been agreed to. The Order of referral and the memorandum of understanding could have been annexed to the Judgment delivered by the Tribunal on 14 March 2012.

The Commission could have been requested to make its recommendations within one year: this would have initiated the second phase of this case. As the Tribunal is at liberty in the performance of its judicial role to define the manner in which it chooses to respond to the parties' submissions, The Tribunal is therefore free to consider and decide the question of delimiting the continental shelf beyond 200 nautical miles separately.

Disputes of this kind may well proliferate in a world in which territorial concerns play a leading role. This was an opportune occasion to establish a procedural precedent that could prove very useful to international courts and tribunals called upon to exercise jurisdiction in these areas.

The system put in place under the Convention corresponds to the notion that some subject matters call for a lighter procedure, one with recourse to experts not lawyers and one in which factual determinations undoubtedly play a more important role than "legal" considerations in the strict sense; this is because scientific questions are answered by science, not law.

Thus, Annex II of the Convention establishes the CLCS, which is tasked with making recommendations to coastal States on matters related to establishing the outer limits of their continental shelf when it extends more than 200 nautical miles from the baselines.

By laying down precise criteria for the determination of the limits of the continental shelf, article 76 dispels the uncertainties having arisen under the1958 Convention, which, among other things, based the 
definition of the continental shelf on exploitability, thereby paving the way to runaway extensions.

Application of the scientific criteria set out in article 76 could not be left solely to the discretion of the coastal State, which remains empowered to determine the course of its boundaries since it establishes the outer edge of the continental margin and delineates the outer limits of its continental shelf. ${ }^{117}$

The Commission was established to provide an independent, objective analysis of the elements of a State's claim in respect of the outer limits of its continental shelf. The Commission has to contribute to determining the definitive course of the outer limits of the continental shelf. It must also act as ethical safeguard by preventing overblown claims.

Maritime delimitation is founded on the notion that the coastal projections of two neighbouring States, each measuring a certain distance from the coast, overlap or are superimposed. Where there are not equal, concurrent entitlements to a given area, there is no call for maritime delimitation. The problem in the present case is that the claimed entitlements are founded more on presumptions than proof, hence the need for recourse to the Commission.

The Tribunal is the guardian and authoritative interpreter of the Convention and is duty-bound to be painstaking in protecting and preserving it.

Open Access This article is distributed under the terms of the Creative Commons Attribution 4.0 International License (http://creativecommons.org/licenses/by/4.0/), which permits unrestricted use, distribution, and reproduction in any medium, provided you give appropriate credit to the original author(s) and the source, provide a link to the Creative Commons license, and indicate if changes were made.

${ }^{117}$ [4 and 7] of article 76. 